\title{
KONTRIBUSI PENGUASAAN KOSAKATA TERHADAP KEMAMPUAN MEMBACA PEMAHAMAN SISWA KELAS XI SMA NEGERI I KUOK KABUPATEN KAMPAR PROVINSI RIAU
}

\author{
Dwi Viora \\ Surel : dwiviora@ymail.com
}

\begin{abstract}
ABSTRAK
Penelitian ini bertujuan menjelaskan seberapa besar kontribusi penguasaan kosakata terhadap kemampuan membaca pemahaman siswa kelas XI SMA Negeri I Kuok Kabupaten Kampar Provinsi Riau. Metode penelitian adalah korelasional. Populasi penelitian adalah siswa kelas XI SMA Negeri I Kuok Kabupaten Kampar Provinsi Riau. Sampel adalah sampel total, yaitu 53 siswa. Instrumen penelitian berupa tes sehingga diperoleh data berupa skor yang diubah ke nilai. Selanjutnya, data dianalisis dengan menggunakan uji korelasi, uji korelasi ganda, uji t, uji F, dan rumus koefisien determinan. Hasil penelitian adalah penguasaan kosakata memberikan kontribusi yang signifikan sebesar $35,3 \%$ terhadap kemampuan membaca pemahaman.
\end{abstract}

Kata Kunci: Penguasaan Kosakata, Membaca, Membaca Pemahaman

\section{PENDAHULUAN}

Keterampilan membaca merupakan salah satu keterampilan berbahasa yang harus dikuasai siswa. Salah satu keterampilan membaca yang harus dikuasai siswa dalam pembelajaran bahasa Indonesia adalah membaca intensif. Membaca intensif merupakan kegiatan membaca yang berorientasi pada proses memahami informasi dalam bahan bacaan. Proses pemahaman bacaan dapat dilakukan dengan kegiatan membaca pemahaman. Dengan demikian, kegiatan membaca pemahaman merupakan bagian dari membaca intensif. Dalam kegiatan membaca diperlukan penguasaan kosakata. Keraf (2006:24) menyatakan bahwa perbendaharaan kata atau kosakata suatu bahasa adalah keseluruhan kata yang dimiliki oleh suatu bahasa.
Semakin banyak perbendaharaan kata yang dimiliki siswa, maka siswa akan mudah memahami isi bacaan. Sebaliknya, semakin sedikit penguasaan kosakata yang dimiliki siswa, maka siswa akan sulit memahami isi bacaan. Pernyataan tersebut sesuai dengan pendapat Nurhadi (2004:3) menjelaskan bahwa kosakata adalah modal utama dalam membaca. Pembaca yang baik memiliki penguasaan kosakata diberbagai bidang ilmu sebagai modal untuk membaca. Semakin luas perbendaharaan kata seseorang, maka semakin memahami isi bacaan. Pendapat tersebut didukung oleh Wainwright (2007:33) yang menyatakan bahwa kosakata adalah faktor yang sangat penting dalam membaca. Semakin banyak seseorang menguasai kosakata maka semakin mudah orang tersebut untuk 

memahami bacaan. Selanjutnya, Tarigan (2011:2) menyatakan bahwa kualitas keterampilan berbahasa seseorang bergantung kepada kuantitas dan kualitas kosakata yang dimilikinya. Semakin banyak kosakata yang dimiliki seseorang, semakin besar pula kemungkinan seseorang terampil berbahasa.

Sejalan dengan pendapat di atas, Tarigan (2011:17) menjelaskan bahwa tingkatan kosakata seorang siswa merupakan indeks yang baik bagi kemampuan mentalnya dan fakta yang diterima secara umum. Ujian kosakata merupakan cara untuk mengetahui IQ para siswa. Berdasarkan beberapa penelitian dijelaskan bahwa ujian kosakata mempunyai korelasi yang tinggi dengan ujian kemampuan membaca.

$$
\text { Berdasarkan beberapa }
$$

pendapat ahli di atas, dapat disimpulkan bahwa penguasaan kosakata adalah kemampuan menguasai perbendaharaan kata dalam suatu bahasa. Penguasaan kosakata seseorang akan menentukan kemampuannya dalam memahami isi bacaan. Seseorang yang memiliki penguasaan kosakata akan mudah memahami isi bacaan, sedangkan orang yang tidak memiliki penguasaan kosakata akan kesulitan memahami isi bacaan. Dengan demikian, dalam membaca pemahaman diperlukan penguasaan kosakata agar bisa memahami isi bacaan secara keseluruhan.

Pernyataan tersebut sesuai dengan hasil penelitian yang dilakukan oleh Samsiyah pada tahun
2013, dengan judul penelitian "Hubungan antara Penguasaan Kosakata dan Motivasi Belajar dengan Kemampuan Membaca Cerita (Survei pada Siswa Kelas V SD Negeri di Kecamatan Jatiroto)", yang menyimpulkan bahwa terdapat hubungan positif yang signifikan antara penguasaan kosakata dan kemampuan membaca cerita siswa. Dengan demikian, apabila dikaitkan dengan kemampuan membaca pemahaman, maka siswa yang memiliki penguasaan kosakata yang tinggi akan memiliki kemampuan membaca pemahaman yang tinggi pula.

Berdasarkan uraian di atas, dapat disimpulkan bahwa penguasaan kosakata memiliki hubungan dengan kemampuan membaca pemahaman. Siswa yang tidak menguasai kosakata akan kesulitan dalam memahami bacaan yang dibacanya. Oleh karena itu, penguasaan kosakata merupakan faktor yang memengaruhi pemahaman siswa terhadap bacaan.

Penelitian ini bertujuan untuk mengetahui seberapa besar kontribusi penguasaan kosakata terhadap kemampuan membaca pemahaman siswa kelas XI SMA Negeri I Kuok Kabupaten Kampar Provinsi Riau. Pemilihan penguasaan kosakata sebagai faktor yang memengaruhi kemampuan membaca pemahaman karena pertimbangan penguasaan kosakata merupakan faktor yang dominan berkontribusi terhadap kemampuan membaca pemahaman. Selain itu, penelitian 
secara ilmiah tentang kontribusi penguasaan kosakata terhadap kemampuan membaca pemahaman siswa di SMA tersebut belum pernah dilakukan.

\section{METODE PENELITIAN}

Penelitian ini termasuk
penelitian deskriptif menggunakan pendekatan kuantitatif dan metode korelasional. Proses pengolahan data dan pendeskripsian analisis data menggunakan rumus statistik. Metode korelasional digunakan untuk menjelaskan hubungan di antara kedua variabel yang diteliti. Menurut Fauzi (2009:25) "pada metode korelasional, hubungan antara variabel diteliti dan dijelaskan. Hubungan yang dicari ini disebut korelasi”. Berdasarkan hubungan tersebut, akan dianalisis lebih lanjut untuk mencari besar sumbangan variabel bebas $(\mathrm{X})$ terhadap variabel terikat (Y).

Populasi penelitian ini adalah semua siswa kelas XI SMA Negeri I Kuok Kabupaten Kampar Provinsi Riau tahun ajaran 2013/2014. Selanjutnya, sampel dalam penelitian ini adalah sampel total. Menurut Bungin (2011:111) "sampel total, yaitu keseluruhan populasi merangkap sebagai sampel penelitian". Pendapat tersebut diperkuat oleh Arikunto (2006:134) yang menyatakan bahwa apabila subjeknya kurang dari 100, lebih baik diambil semua sehingga penelitiannya merupakan penelitian populasi. Dengan demikian, sampel penelitian ini adalah 53 orang siswa.

Penelitian ini menggunakan instrumen tes. Tes digunakan untuk mengum-pulkan data penguasaan kosakata dan kemampuan membaca pemahaman yang dibuat dalam bentuk tes objektif. Indikator tes penguasaan kosakata disusun berdasarkan pendapat Djiwandono (2011:127-128), yaitu (1) mampu memahami makna kata dalam kalimat atau paragraf; (2) mampu menentukan kata yang memiliki arti yang sama atau mirip dengan suatu kata (sinonim) dalam kalimat atau paragraf, (3) mampu menentukan kata yang memiliki arti yang berlawanan dengan suatu kata (antonim) dalam kalimat atau paragraf. Selanjutnya, indikator tes kemampuan membaca pemahaman disusun berdasarkan pendapat Razak (2005:11), yaitu mampu menentukan (1) gagasan pokok atau kalimat pokok; (2) gagasan penjelas atau kalimat penjelas; (3) simpulan bacaan. Sebelum soal ini digunakan terlebih dahulu dilakukan uji coba soal.

Data penelitian ini berupa skor yang diubah ke dalam bentuk nilai. Selanjutnya, data di analisis dengan menggunakan uji korelasi Pearson Product Moment (PPM), uji korelasi ganda, uji t, uji F, dan rumus koefisien determinan untuk mengetahui besar kontribusi variabel bebas terhadap variabel terikat. Sebelum data dianalisis, terlebih dahulu dilakukan uji persyaratan 
analisis, yaitu uji normalitas, homogenitas, dan linieritas.

\section{HASIL PENELITIAN DAN PEMBAHASAN}

Data penguasaan kosakata didapat dari nilai yang diperoleh setiap siswa. Nilai tersebut diperoleh dari tes penguasaan kosakata yang terdiri atas 29 butir soal yang berbentuk tes objektif. Skor maksimal yang bisa diperoleh siswa adalah 31 dan skor minimal adalah 0 . Berdasarkan hasil analisis data diperoleh nilai tertinggi sebesar 90 dan nilai terendah 42 , nilai rata-rata penguasaan kosakata sebesar 66,66 , median 67,26, modus 66,77, dan standar deviasi sebesr 10,66. Berdasarkan tabel interval persentase tingkat penguasaan, penguasaan kosakata siswa kelas XI SMA Negeri I Kuok Kabupaten Kampar Provinsi Riau tergolong cukup, yaitu sebesar 66,66 .

Gambaran mengenai distribusi frekuensi nilai penguasaan kosakata dibuat dalam bentuk tabel distribusi frekuensi. Dalam menentukan distribusi frekuensi nilai penguasaan kosakata siswa, ada beberapa hal yang perlu ditentukan terlebih dahulu, yaitu: (1) range, selisih antara nilai maksimal dengan nilai minimal $=90-42=48$; (2) banyak kelas interval $=1+3,3 \log n$ $=1+3,3 \log (53)=1+5,676=$ 6,676 dibulatkan menjadi 7; (3) panjang kelas $=$ range dibagi banyak kelas $=48 / 7=6,86$ dibulatkan menjadi 7. Berikut tabel distribusi frekuensi dari variabel penguasaan kosakata.

Tabel Distribusi Frekuensi Data Penguasaan Kosakata

\begin{tabular}{|c|c|c|c|}
\hline No. & $\begin{array}{c}\text { Kelas } \\
\text { Interval }\end{array}$ & Frekuensi & $\begin{array}{c}\text { Frekuensi } \\
\text { Relatif } \\
(\%)\end{array}$ \\
\hline 1. & $42-$ & 4 & 8 \\
\hline 2. & $49-$ & 5 & 9 \\
\hline 3. & $56-$ & 6 & 11 \\
\hline 4. & $63-$ & 17 & 32 \\
\hline 5. & $70-$ & 10 & 19 \\
\hline 6. & $77-$ & 10 & 19 \\
\hline 7. & 84 & & \\
& 90 & 1 & 2 \\
\hline Jumlah & & 53 & 100 \\
\hline
\end{tabular}

Berdasarkan tabel distribusi frekuensi data penguasaan kosakata di atas, dapat diketahui bahwa 17 orang siswa atau $32 \%$ dari jumlah siswa memperoleh nilai kelompok rata-rata, yaitu 66,66. Siswa yang memperoleh nilai di bawah kelas interval rata-rata berjumlah 15 orang siswa atau sebesar $28 \%$, sedangkan siswa yang memperoleh nilai di atas kelas interval rata-rata berjumlah 21 orang siswa atau sebesar $40 \%$. Berikut ini gambaran penguasaan kosakata siswa kelas XI SMA Negeri I Kuok Kabupaten Kampar Provinsi Riau yang dibuat dalam bentuk histogram. 


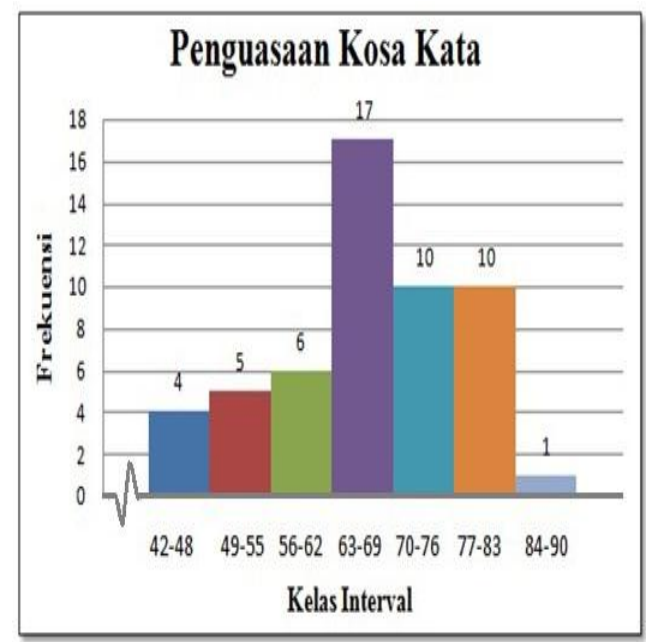

\section{Grafik Histogram Distribusi Nilai Penguasaan Kosakata}

Data kemampuan membaca pemahaman didapat dari nilai yang diperoleh setiap siswa. Nilai tersebut diperoleh dari tes kemampuan membaca pemahaman yang terdiri atas 29 butir soal yang berbentuk tes objektif. Skor maksimal yang bisa diperoleh siswa adalah 29 dan skor minimal adalah 0. Berdasarkan hasil analisis data diperoleh nilai tertinggi sebesar 90 dan nilai terendah 34, nilai rata-rata kemampuan membaca pemahaman sebesar 66,48, median 66,20, modus 64,94, dan standar deviasi sebesar 9,83. Berdasarkan tabel interval persentase tingkat penguasaan, kemampuan membaca pemahaman siswa kelas XI SMA Negeri I Kuok Kabupaten Kampar Provinsi Riau tergolong cukup, yaitu sebesar 66,48.

Gambaran mengenai distribusi frekuensi nilai kemampuan membaca pemahaman dibuat dalam bentuk tabel distribusi frekuensi. Dalam menentukan distribusi frekuensi nilai kemampuan membaca pemahaman siswa, ada beberapa hal yang perlu ditentukan terlebih dahulu, yaitu: (1) range, selisih antara nilai maksimal dengan nilai minimal $=90-34=56$; (2) banyak kelas interval $=1+3,3 \log n$ $=1+3,3 \log (53)=1+5,676=$ 6,676 dibulatkan menjadi 7; (3) panjang kelas = range dibagi banyak kelas $=56 / 7=8$. Berikut tabel distribusi frekuensi dari variabel kemampuan membaca pemahaman.

Tabel Distribusi Frekuensi Data Kemampuan Membaca Pemahaman

\begin{tabular}{|c|c|c|c|}
\hline No & $\begin{array}{c}\text { Kelas } \\
\text { Interval }\end{array}$ & Frekuensi & $\begin{array}{c}\text { Frekuensi } \\
\text { Relatif } \\
(\%)\end{array}$ \\
\hline 1. & $3_{41}{ }^{-}$ & 1 & 2 \\
\hline 2. & $4249^{-}$ & 1 & 2 \\
\hline 3. & ${ }^{50}{ }^{57}-$ & 5 & 9 \\
\hline 4. & ${ }^{58} 65^{-}$ & 18 & 34 \\
\hline 5. & $\begin{array}{ll}66 & - \\
73 & \end{array}$ & 17 & 32 \\
\hline 6. & $\begin{aligned} & 74- \\
& 81 \\
&\end{aligned}$ & 7 & 13 \\
\hline 7. & ${ }_{82}^{82}$ & 4 & 8 \\
\hline Jum & & 53 & 100 \\
\hline
\end{tabular}

Berdasarkan tabel distribusi frekuensi data kemampuan membaca pemahaman di atas, dapat diketahui bahwa 17 orang siswa atau $32 \%$ dari jumlah siswa memperoleh nilai kelompok rata-rata, yaitu 66,48. Siswa yang memperoleh nilai di bawah kelas interval rata-rata berjumlah 25 orang siswa atau sebesar $47 \%$, sedangkan siswa yang memperoleh nilai di atas kelas interval rata-rata berjumlah 11 orang 
siswa atau sebesar 21\%. Berikut gambaran kemampuan membaca pemahaman siswa kelas XI SMA Negeri I Kuok Kabupaten Kampar Provinsi Riau yang dibuat dalam bentuk histogram.

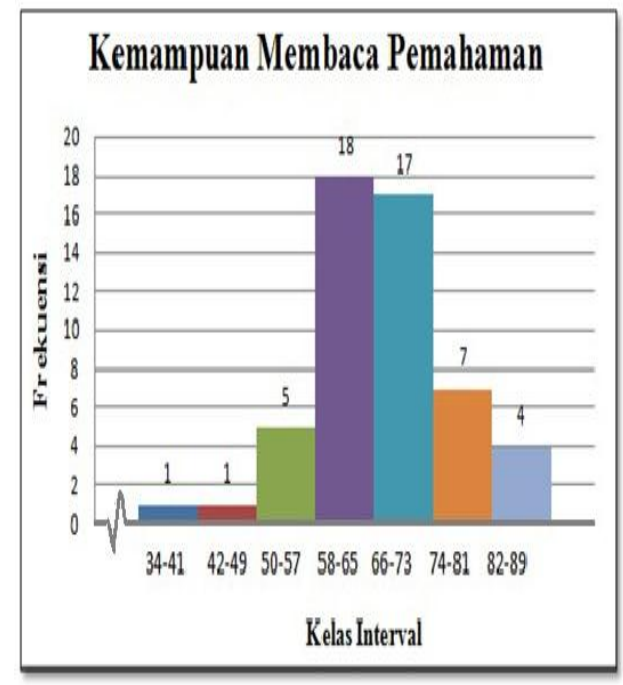

Grafik Histogram Distribusi Nilai Kemampuan Membaca Pemahaman

Hipotesis yang diajukan dalam penelitian ini adalah penguasaan kosakata (X) berkontribusi secara signifikan terhadap kemampuan membaca pemahaman (Y) siswa kelas XI SMA Negeri I Kuok Kabupaten Kampar Provinsi Riau. Pengujian hipotesis yang dilakukan adalah sebagai berikut:

$\mathrm{H}_{\mathrm{a}}$ : Terdapat kontribusi penguasaan kosakata yang signifikan terhadap kemampuan membaca pemahaman siswa kelas XI SMA Negeri I Kuok Kabupaten Kampar Provinsi Riau.

$\mathrm{H}_{0}$ : Tidak terdapat kontribusi penguasaan kosakata yang signifikan terhadap kemampuan membaca pemahaman siswa kelas XI SMA Negeri I Kuok Kabupaten Kampar Provinsi Riau.

Dalam membuktikan hipotesis di atas, maka dilakukan pengujian hipotesis dengan menggunakan rumus uji korelasi Pearson Product Moment. Setelah diketahui hubungan antara penguasaan kosakata dengan kemampuan membaca pemahaman, maka dicari besar kontribusi penguasaan kosakata terhadap kemampuan membaca pemahaman. Hasil penghitungan pengujian hipotesis adalah sebagai berikut:

\section{Tabel Uji Hipotesis}

\begin{tabular}{|c|c|c|c|c|}
\hline \multirow[t]{2}{*}{$\begin{array}{c}\text { Korelasi } \\
\text { antara } \\
\text { Variabel }\end{array}$} & \multirow{2}{*}{$\begin{array}{c}\text { Koefisi } \\
\text { en } \\
\text { Korela } \\
\text { si }\left(r_{x 2 y}\right)\end{array}$} & \multirow[t]{2}{*}{$\begin{array}{c}\text { Koefisien } \\
\text { Determin } \\
\text { asi }(\mathbf{K P})\end{array}$} & \multirow[t]{2}{*}{$\begin{array}{c}\text { thitu } \\
\text { ng }\end{array}$} & $t_{\text {tabel }}$ \\
\hline & & & & $\begin{array}{c}\alpha= \\
0,05\end{array}$ \\
\hline $\begin{array}{l}\text { Penguasa } \\
\text { an } \\
\text { Kosakata } \\
(\mathrm{X}) \\
\text { terhadap } \\
\text { Kemamp } \\
\text { uan } \\
\text { Membaca } \\
\text { Pemaham } \\
\text { an (Y) }\end{array}$ & 0,594 & $35,3 \%$ & 5,27 & $\begin{array}{c}1,68 \\
4\end{array}$ \\
\hline
\end{tabular}

Berdasarkan tabel di atas, dapat diketahui bahwa variabel penguasaan kosakata $(\mathrm{X})$ berkorelasi dengan kemampuan membaca pemahaman (Y) sebesar 0,594. Berdasarkan interpretasi koefisien korelasi nilai r, maka korelasi penguasaan kosakata dengan kemampuan membaca pemahaman tergolong cukup. Selanjutnya, besar 
sumbangan variabel penguasaan kosakata (X) terhadap variabel kemampuan membaca pemahaman (Y) adalah sebesar 35,3\%. Hal ini menunjukkan bahwa kemampuan membaca pemahaman (Y) dipengaruhi sebesar $35,3 \%$ oleh penguasaan kosakata $(\mathrm{X})$, sedangkan sisanya dipengaruhi oleh faktor lain. Dengan demikian, semakin tinggi penguasaan kosakata, maka semakin tinggi kemampuan membaca pemahaman siswa kelas XI SMA Negeri I Kuok Kabupaten Kampar Provinsi Riau.

Dalam menguji signifikansi besar sumbangan penguasaan kosakata (X) terhadap kemampuan membaca pemahaman (Y), maka dilakukan uji signifikansi dengan uji $\mathrm{t}$ dan membandingkan nilai thitung dengan $t_{\text {tabel. }}$. Kaidah pengujiannya, jika $t_{\text {hitung }} \geq \mathrm{t}_{\text {tabel, }}$, maka signifikan, jika $t_{\text {hitung }} \leq \mathrm{t}_{\text {tabel, }}$ maka tidak signifikan. Berdasarkan uji signifikansi dengan menggunakan uji $\mathrm{t}$ diperoleh nilai thitung sebesar 5,27 dan tabel dengan tingkat kesalahan $\alpha$ $=0,05$ dan $\mathrm{db}=\mathrm{n}-2=53-2=51$ sebesar 1,684, berarti thitung $>t_{\text {tabel }}$ atau 5,27>1,684. Dengan demikian, $\mathrm{H}_{0}$ ditolak dan $\mathrm{H}_{\mathrm{a}}$ diterima, berarti hipotesis yang berbunyi penguasaan kosakata berkontribusi secara signifikan terhadap kemampuan membaca pemahaman siswa kelas XI SMA Negeri I Kuok Kabupaten Kampar Provinsi Riau dapat diterima.

Selanjutnya, berdasarkan uji linieritas model regresi yang telah dilakukan dalam persyaratan analisis terhadap pasangan data penguasaan kosakata dan kemampuan membaca pemahaman diperoleh koefisien arah regresi (b) sebesar 0,58 dan konstanta (a) sebesar 28,72. Dengan demikian, kontribusi penguasaan kosakata terhadap kemampuan membaca pemahaman dapat dinyatakan dengan persamaan regresi $\hat{\mathrm{Y}}=28,72+0,58 \mathrm{X}_{2}$. Hal ini menunjukkan bahwa, jika tidak ada penguasaan kosakata pada diri siswa atau $X=0$, maka nilai kemampuan membaca pemahaman siswa telah ada sebesar 28,72. Persamaan regresi tersebut bisa digunakan untuk prediksi, yaitu apabila penguasaan kosakata siswa diperbaiki satu nilai, maka kemampuan membaca pemahaman $(\mathrm{Y})$ meningkat sebesar 0,58 . Oleh karena itu, bila ingin meningkatkan kemampuan membaca pemahaman siswa, maka penguasaan kosakata mereka harus ditingkatkan.

\section{Pembahasan}

Temuan penelitian ini sejalan dengan hasil penelitian Arizon (2008) yang menyatakan bahwa semakin tinggi penguasaan makna kata yang dimiliki oleh siswa, maka hasil belajar bahasa Indonesia siswa juga cenderung meningkat. Selanjutnya, temuan penelitian ini juga sesuai dengan pendapat Nurhadi (2004:3) yang menjelaskan bahwa kosakata adalah modal utama dalam membaca. Pembaca yang baik memiliki penguasaan kosakata di berbagai bidang ilmu sebagai modal untuk membaca. Semakin luas perbendaharaan kata seseorang, 
maka semakin memahami isi bacaan. Pendapat tersebut juga didukung oleh Wainwright (2007:33) yang menyatakan bahwa kosakata adalah faktor yang sangat penting dalam membaca. Semakin banyak seseorang menguasai kosakata maka semakin mudah orang tersebut memahami bacaan. Selanjutnya, Tarigan (2011:17) juga menyatakan bahwa tingkatan kosakata seorang siswa merupakan indeks yang baik bagi kemampuan mentalnya dan fakta yang diterima secara umum. Ujian kosakata merupakan cara untuk mengetahui IQ para siswa. Dari beberapa penelitian dijelaskan bahwa ujian kosakata mempunyai korelasi yang tinggi dengan ujian kemampuan membaca.

Temuan penelitian ini juga didukung oleh Atmazaki (2006:54) yang menjelaskan bahwa penguasan kosakata dapat ditambah dengan berbagai cara, yaitu dengan mencari dan menguasainya melalui kamus, baik kamus umum maupun kamus khusus, seperti kamus sinonim, kamus istilah ilmu pengetahuan, dan kamus ungkapan. Penguasaan kosakata juga bisa meningkat dengan memilih kata karena nuansa dan keluasan maknanya. Seseorang memilih kata dengan alasan tertentu sehingga dasar pemilihan katanya juga tertentu. Selanjutnya, Tarigan (2008:15) menyatakan bahwa ada beberapa cara yang bisa dilakukan guru untuk memperkaya kosakata siswa, yaitu memperkenalkan sinonim kata, antonim kata, parafrase, kata-kata yang berdasar sama; memperkenalkan imbuhan yang mencakup awalan, sisipan, dan akhiran; dan mengira-ngira atau menerka makna kata dalam teks berdasarkan konteksnya dalam teks.

Berdasarkan hasil penelitian dan beberapa pendapat ahli di atas, dapat disimpulkan bahwa penguasaan kosakata memiliki peranan yang penting dalam membaca. Penguasaan kosakata siswa akan meningkatkan kemampuan mereka dalam memahami isi bacaan. Hal ini disebabkan siswa yang memiliki penguasaan kosakata yang banyak akan memudahkan mereka memahami isi bacaan. Peningkatan penguasaan kosakata akan meningkatkan kemampuan membaca pemahaman. Selain itu, penguasaan kosakata siswa bisa ditingkatkan dengan sering melakukan kegiatan membaca.

Sebagaimana pernyataan yang telah diuraikan dalam latar belakang penelitian bahwa penguasaan kosakata memiliki hubungan dengan kemampuan membaca pemahaman, maka pernyataan tersebut telah dibuktikan dengan hasil penelitian. Hasil penelitian menunjukkan bahwa penguasaan kosakata memberikan kontribusi yang signifikan terhadap kemampuan membaca pemahaman. Penguasaan kosakata merupakan satu di antara sekian banyak faktor yang memberikan sumbangan terhadap kemampuan membaca pemahaman siswa kelas XI SMA Negeri I Kuok Kabupaten Kampar Provinsi Riau. 
Semakin banyak penguasaan kosakata siswa, maka semakin tinggi kemampuan membaca pemahaman mereka. Hal ini disebabkan penguasaan kosakata akan memudahkan siswa memahami isi bacaan. Jadi, rendahnya nilai kemampuan membaca pemahaman siswa bisa ditingkatkan dengan meningkatkan penguasaan kosakata mereka. Oleh karena itu, guru harus meningkatkan penguasaan kosakata siswa agar kemampuan membaca pemahaman mereka meningkat.

$$
\text { Berdasarkan temuan }
$$

penelitian tersebut juga dapat disimpulkan bahwa penguasaan kosakata siswa kelas XI SMA Negeri I Kuok Kabupaten Kampar Provinsi Riau harus ditingkatkan karena tingkat pencapaian tes penguasaan kosakata siswa tersebut masih berkategori cukup. Tingkat pencapaian penguasaan kosakata siswa tersebut disebabkan oleh jarangnya siswa melakukan kegiatan membaca sehingga penguasaan kosakatanya terbatas. Dalam meningkatkan penguasaan kosakata siswa dibutuhkan peran guru. Guru harus bisa meningkatkan penguasaan kosakata siswa dengan memberikan tugas membaca kepada mereka. Kemudian, mereka disuruh mencari makna dari kata-kata sulit di dalam kamus sehingga penguasaan kosakata mereka meningkat.

Selanjutnya, hasil analisis penguasaan kosakata siswa per indikator, yaitu: (1) mampu memahami makna kata dalam kalimat atau paragraf diperoleh nilai sebesar 469,81 dan nilai rata-rata sebesar 52,20; (2) mampu menentukan kata yang memiliki arti yang sama atau mirip dengan suatu kata (sinonim) dalam kalimat atau paragraf diperoleh nilai sebesar 869,81 dan nilai rata-rata sebesar 79,07; (3) mampu menentukan kata yang memiliki arti yang berlawanan dengan suatu kata (antonim) dalam kalimat atau paragraf diperoleh nilai sebesar 720,75 dan nilai rata-rata sebesar 65,52. Berdasarkan hasil analisis terhadap ketiga indikator penguasaan kosakata tersebut, indikator yang mendapat nilai ratarata paling rendah adalah indikator pertama, yaitu mampu memahami makna kata dalam kalimat atau paragraf. Rendahnya nilai pada indikator pertama ini disebabkan jarangnya siswa melakukan kegiatan membaca sehingga penguasaan kosakata mereka juga terbatas. Kosakata siswa akan meningkat apabila selalu melakukan kegiatan membaca. Peningkatan penguasaan kosakata siswa akan memudahkan mereka memahami isi bacaan. Oleh karena itu, sebaiknya di dalam kelas disediakan kamus yang dapat memudahkan siswa untuk mencari makna kata-kata sulit yang ditemukan dalam bacaan.

\section{SIMPULAN}

Penelitian ini membahas
tentang kontribusi penguasaan
kosakata terhadap kemampuan
membaca pemahaman siswa kelas XI
SMA Negeri I Kuok Kabupaten
Kampar Provinsi Riau. Berdasarkan


hasil penelitian dan pembahasan diperoleh simpulan bahwa penguasaan kosakata memberikan kontribusi yang signifikan terhadap kemampuan membaca pemahaman siswa kelas XI SMA Negeri I Kuok Kabupaten Kampar Provinsi Riau, yaitu sebesar 35,3\%. Temuan penelitian ini menunjukkan bahwa semakin banyak penguasaan kosakata siswa, maka semakin tinggi kemampuan membaca pemahaman mereka. Hal ini disebabkan penguasaan kosakata diperlukan dalam memahami isi bacaan. Oleh karena itu, guru harus memberikan pelatihan-pelatihan yang memungkinkan siswa memperbanyak penguasaan kosakatanya sehingga memudahkan mereka dalam memahami isi bacaan.

\section{DAFTAR RUJUKAN}

Arizon. 2008. Kontribusi Kecepatan Efektif Membaca (KEM) dan Penguasaan Makna Kata terhadap Hasil Belajar Bahasa Indonesia Siswa Kelas $X$ SMAN 1 Akabiluru. Tesis tidak diterbitkan. Padang: Program Pascasarjana Universitas Negeri Padang.

Atmazaki. 2006. Kiat-Kiat Mengarang dan Menyunting. Padang: Yayasan Citra Budaya Indonesia.

Bungin, M. Burhan. 2011. Metodologi Penelitian Kuantitatif Komunikasi, Ekonomi, dan Kebijakan
Publik serta Ilmu-Ilmu Sosial lainnya. Jakarta: Kencana.

Djiwandono, Soenardi. 2011. Tes Bahasa Pegangan bagi Pengajar Bahasa. Jakarta: Indeks.

Fauzi, Muchamad. 2009. Metode Penelitian Kuantitatif Sebuah Pengantar. Semarang: Walisongo Press.

Keraf, Gorys. 2006. Diksi dan Gaya Bahasa. Jakarta: Gramedia Pustaka Utama.

Samsiyah, Siti, dkk. 2013. Hubungan antara Penguasaan Kosakata dan Motivasi Belajar dengan Kemampuan Membaca Cerita (Survei pada Siswa Kelas V SD Negeri di Kecamatan Jatiroto). Jurnal Pendidikan bahasa dan sastra. Universitas Sebelas Maret Surakarta. (Online), Vol. 1 , No. 1, (http:// jurnal.pasca.uns.ac.id, diakses 15 Juli 2013).

Tarigan, Henry Guntur. 2008. Membaca Sebagai Suatu Keterampilan Berbahasa (Edisi Revisi). Bandung: Angkasa.

Tarigan, Henry Guntur. 2011. Pengajaran Kosakata (Edisi Revisi). Bandung: Angkasa.

Wainwright, Gorden. 2007. Speed Reading Better Recalling Manfaat Teknik-Teknik Teruji untuk Membaca Lebih Cepat dan Mengingat secara Maksimal. Jakarta: Gremedia Pustaka Utama. 